1 This manuscript is contextually identical with the following published paper:

2 Mojzes, A., Csontos, P. \& Kalapos, T. (2015) Is the positive response of seed germination to

3 plant-derived smoke associated with plant traits? Acta Oecologica 65-66: 24-31.

4 doi:10.1016/j.actao.2015.05.001

5 The original published pdf available in this website:

6 http://www.sciencedirect.com/science/article/pii/S1146609X15000521

7

8

9

10

11 Is the positive response of seed germination to plant-derived smoke associated with plant 12 traits?

13

14

15

16

17

18

19

20

21 Corresponding author, present address: Andrea Mojzes; Institute of Ecology and Botany,

22 MTA Centre for Ecological Research, Alkotmány u. 2-4., H-2163 Vácrátót, Hungary; E-mail: mojzesandrea@gmail.com; Tel.: +3628360122; Fax: +3628360110

Andrea Mojzes $^{\mathrm{a}}$, Péter Csontos $^{\mathrm{b}}$ and Tibor Kalapos $^{\mathrm{a}}$

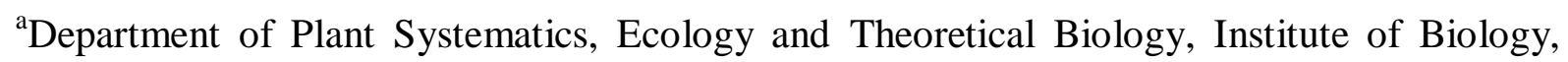
Eötvös Loránd University, Pázmány P. s. 1/C., H-1117 Budapest, Hungary

${ }^{\mathrm{b}}$ Institute for Soil Science and Agricultural Chemistry, Centre for Agricultural Research, Hungarian Academy of Sciences, Herman O. út 15., H-1022 Budapest, Hungary 4 
Is the positive response of seed germination to plant-derived smoke associated with

\section{plant traits?}

\section{Abstract}

Relationships between seed germination response to plant-derived smoke and various plant traits (habitat requirements, life form, seed morphology, seed bank type) were analyzed for 97 species of the Hungarian flora using published data. It was hypothesized that smokeresponsive species - those displaying enhanced germination in response to smoke - differ from non-responsive species - smoke having an indifferent or inhibitory effect on germination - in habitat requirements and/or certain life history traits. To our knowledge, no such comparison has previously been reported for a European flora. We found that species indicating disturbance and those preferring soils rich or moderately rich in nitrogen were more frequent in the smoke-responsive group ( $80 \%$ and $41 \%$, respectively) than in the nonresponsive group, while the non-responsive group contained a high percentage of natural species (i.e. species dominant or characteristic in natural plant communities; 47\%) and species indicative of nutrient poor $(38 \%)$ or (sub)mesotrophic (38\%) soils. Annuals or biennials (67\%) dominated the smoke-responsive group, whereas in the non-responsive group these short-lived species and perennial herbs were equally abundant (43\% each). There was a tendency for higher frequency of long-term persistent seed bank among smoke-responsive species $(78 \%)$ than in the non-responsive group (54\%). These findings suggest that smokestimulated germination is associated with only a few specific plant traits for species from a semiarid temperate region of Europe, but highlight the frequent occurrence of smokeenhanced germination among short-lived, nitrophilous or disturbance tolerant species. These 
results can contribute to a better understanding of post-fire regeneration of plant communities, and could also be considered during vegetation restoration or weed management.

Keywords: ecological indicator values, fire, life form, seed properties, temperate species, weeds

\section{Introduction}

Seed dormancy and germination characteristics of plant species may vary depending on habitats (Baskin and Baskin 1988; Schütz 2000; Thompson et al. 1977, 1998) and the species' life history strategies for regeneration (Keeley 1991; Thompson et al. 1998). For example, in the genus Carex, Schütz (2000) reported that species growing in forests germinated earlier in spring and at lower temperatures than the species of open habitats. In the fire-prone California chaparral, Keeley (1991) classified two post-fire regeneration strategies differing markedly in seed characteristics (seed bank type, dormancy, seed mass and dispersal mode) and the timing of germination. Most fire-resister shrubs with vegetative resprouting capacity recruit by heavy, non-refractory seeds dispersed by birds, and lack seed dormancy and a persistent soil seed bank. Their germination typically occurs in the first rainy season following dispersal, in the absence of fire-related cues, such as heat shock or chemicals leached from charred wood. In contrast, fire-recruiter species usually have locally dispersed, refractory seeds with lower seed weight, which persist in the soil seed bank until their dormancy is broken by fire-related stimuli, and germinate in late winter or early spring (Keeley 1991).

In addition to heat and charred wood, smoke derived from burning vegetation is another product of fires that can provide a cue for triggering seed germination. Since the discovery of the phenomenon (De Lange and Boucher 1990), plant-derived smoke and its aqueous solution 
(smoke-water) has been shown to stimulate germination for more than 1200 species from phylogenetically distant plant families and different continents (Dixon et al. 2009; Kulkarni et al. 2011). The phenomenon is particularly frequent in fire-prone Mediterranean ecosystems (Baskin and Baskin 1998; Brown et al. 2003; Dixon et al. 1995; Keeley and Bond 1997; Moreira et al. 2010), but it has also been recorded for several species of non-fire-prone semideserts (Merritt et al. 2006; Pierce et al. 1995), arable weeds (Adkins and Peters 2001; Stevens et al. 2007) and cultivated plants (Kulkarni et al. 2011). The germination stimulating capacity is mainly attributed to karrikinolide (3-methyl-2H-furo[2,3-c]pyran-2-one), a butenolide compound identified in smoke (Flematti et al. 2009). In fire-prone ecosystems, the germination response to smoke appeared to be mostly independent of fire regeneration strategy, life form, seed mass and dispersal mode (Abella 2009; Brown et al. 2003; Dixon et al. 1995). In a test of 221 fynbos species, Brown et al. (2003) found that smoke-enhanced germination showed only weak positive relationships with herbaceous perennial life form and wind seed dispersal mode, and suggested that the smoke response is evolutionarily neutral. Only few such extensive analyses investigating the association between germination response to smoke and life history traits has been published for species from temperate regions (e.g. Tsuyuzaki and Miyoshi 2009), and - to the best of our knowledge - have not been reported for a European flora. Human-induced fire as a management tool has long been and still is an important factor forming the European landscape (Deák et al. 2014; Feurdean et al. 2012; Goldammer and Bruce 2004; Niklasson et al. 2010). In addition, climate change is predicted to increase fire frequency in a large part of the world including most of Europe in the $21^{\text {st }}$ century (Pechony and Shindell 2010). Thus, assessing the germination response to smoke and its relationships with specific plant traits of the species might contribute to a better understanding and predicting of the regeneration processes of plant communities in this region. 
In this study we examine whether the benefit of smoke-stimulated germination varies depending on the prevailing habitat conditions and the life history characteristics of species

101 from a semiarid temperate region of Europe. We hypothesized that species displaying positive 102 germination responses to smoke differ from those lacking smoke-enhanced germination in 103 ecological attributes indicating their habitat requirements or preferences $\left(\mathrm{H}_{1}\right)$, and/or in 104 certain life history traits associated with regeneration (seed properties and life from, $\mathrm{H}_{2}$ ).

105 Based on the literature and our own experiments, these two hypotheses were tested on 97 species of the Hungarian flora. As fire has frequently been linked to human land use in the

107 Carpathian region over the last 1000 years (Deák et al. 2014; Feurdean et al. 2012), we expect 108 that smoke-enhanced germination favours plant traits that are often associated with 109 disturbances in general, e.g. short-lived life forms, preference for nitrogen and light, small 110 seeds and a long-term persistent seed bank (Belsky 1992; Ghermandi et al. 2004; Šoltés et al. 111 2010; Thompson et al. 1998; Török et al. 2008).

\section{Materials and Methods}

An extensive literature search was conducted for laboratory and field studies published between 1998 and 2014 (up to 31 March) on the effect of smoke treatment on the germination or seedling establishment of species belonging to the Hungarian flora (native and naturalized

118 alien species; Király 2009). The collated database contains the germination response to smoke 119 treatment for 97 species (Appendix A), which was collected from 33 studies (Appendix B)

120 supplemented with our own unpublished results. The unpublished data were obtained by using 121 the same experimental methods as described in Mojzes and Kalapos (2014). Data were assessed at species level, even when in the original published study the smoke response was

123 reported for a particular subspecies or variety of a species. In the case of nomenclatural 
synonyms, The International Plant Names Index (2012) was used for species identification.

125 The smoke response of species, quantified in germination percentage or seedling density 126 depending on the study, is expressed as binary data. Positive (+) response was attributed to a species if it significantly $(p<0.05)$ displayed inherent or inducible smoke-stimulated 128 germination (sensu Long et al. 2011) at least under one particular experimental condition, 129 even if under other circumstances smoke treatment had a neutral or inhibitory effect (e.g. due 130 to high concentrations of smoke-water applied: Adkins and Peters 2001; Light et al. 2002, or 131 dormancy that should be alleviated so that seeds become sensitive to smoke: Baker et al. 132 2005; Long et al. 2011). Such species are referred to as 'smoke-responsive' hereafter in this 133 study. In order to analyze the smoke response itself, data describing the effects of combined 134 treatment (e.g. smoke and heat) compared to the untreated control, were excluded. Negative

135 (-) response was assigned to a species if it has not displayed smoke-enhanced germination under any of the conditions tested, i.e. germination was not affected by smoke treatment

137 (undetected response according to Long et al. 2011) or it decreased compared to the control.

138 For such species, the term 'non-responsive to smoke' is used in this study. Different types of 139 smoke treatment, such as aerosol smoke, smoke-water or karrikinolide applied to seeds 140 directly or to the germination medium, were not distinguished (each referred to as 'smoke 141 treatment' in this study). The reason for this was to assess more general associations between 142 the smoke response and other (seed morphological and ecological) plant traits and ensure a 143 sufficient sample size for the analysis.

144 The following plant traits were included in the analysis: thousand-seed mass (TSM; g), 145 deviation of seed shape from sphericity measured by the variance of seed dimensions (length, 146 width and thickness, after transforming each value so that width is unity, a method very 147 similar to that described by Thompson et al. 1993), seed mass category (following the 148 categorization of Hodgson et al. 1995), seed bank type (according to the definition of 
149 Thompson et al. 1997), Raunkiaer life form (categorized by Soó 1964-1985), tolerance of

150 habitat disturbance (Simon 1988) and ecological indicator values (sensu Ellenberg adjusted

151 for the Hungarian situation by Borhidi (1995) reflecting the relative soil nitrogen (N), soil

152 moisture $(\mathrm{W})$, soil reaction (i.e. soil $\mathrm{pH} ; \mathrm{R}$ ), temperature (in accordance with the temperature

153 regime of vegetation zones (T) and light (L) levels of the habitat (Appendix A). Seed size and

154 shape data were extracted from published literature, mainly from the seed atlas of Schermann

155 (1967), or were measured directly. In the latter case, mature seeds were harvested from wild

156 populations growing in habitats typical for the species. Whenever possible, pooled seed

157 samples from several mother plants of the same stand were collected to avoid bias caused by

158 maternal effects. Seed samples were stored in paper bags at room temperature. Thousand-seed

159 mass data were calculated from measurement of $3 \times 100$ fully ripened seeds, weighed to an

160 accuracy of $0.1 \mathrm{mg}$. Seed shape data were calculated from measurement of 10 seeds per

161 species. Seed length and width were measured under a binocular microscope equipped with a

162 measuring lens to the accuracy of $0.1 \mathrm{~mm}$, and seed thickness was measured with a precision

163 of $0.05 \mathrm{~mm}$ by using a thickness meter (Mitutoyo, Japan). Seed bank type data were collected

164 from published literature, mainly from the database of Thompson et al. (1997).

165 For seed mass and the deviation of seed shape from sphericity, statistical comparisons

166 between the two groups of species characterized by positive or negative germination response

167 to smoke were made by two-sample t-tests (Quinn and Keough 2002). Data were log-

168 transformed to meet the normality and homoscedasticity assumptions of the test. For

169 categorical variables, the frequency distributions of species were compared between the two

170 groups by using a Chi-square test of homogeneity. For each variable, categories were pooled

171 in such a way as to meet the assumption that no more than $20 \%$ of the expected frequencies

172 were less than 5 (Quinn and Keough 2002). In each comparison, differences were considered 
173 significant at $p<0.05$. For the analyses, the GraphPad InStat 3.05 (GraphPad Software, San

174 Diego, California, USA) package was used.

175

\section{Results}

177

Among the ecological attributes reflecting habitat conditions, the level of disturbance of

179 the species' typical habitat and the relative nitrogen requirement $(\mathrm{N})$ displayed significantly 180 and markedly different frequency distributions between the two species groups (Fig. 1). In the

181 smoke-responsive group, the proportion of species indicative of habitat disturbance exceeded

182 four times the proportion of natural species (i.e. species dominant or characteristic in natural 183 plant communities; Fig. 1a). Eighty four percent of species associated with habitat disturbance 184 are weeds (i.e. constituents of segetal or ruderal weed communities associated with 185 anthropogenic disturbance). In contrast, in the group of species non-responsive to smoke, 186 species associated with natural or disturbed habitats were represented similarly (47\% and $18753 \%$, respectively; Fig. 1a). Furthermore, in the non-responsive group, the proportion of 188 weeds was much less (48\% of species characteristic in disturbed habitats) in favour of

189 disturbance tolerant native species (37\%). In the smoke-responsive group, a substantial 190 proportion $(41 \%)$ of species preferred soils rich or moderately rich in nitrogen $(\mathrm{N}=6-7)$,

191 while in the species group non-responsive to smoke, about three quarters of the species were 192 characteristic of nutrient poor $(\mathrm{N}=1-3)$ or (sub)mesotrophic $(\mathrm{N}=4-5)$ habitats (38\% each; 193 Fig. 1b). No significant differences were found between the two species groups in the 194 distribution of relative soil moisture (W), soil reaction (R), habitat temperature (T) and light 195 (L) requirements (Figs. 1c-f). 


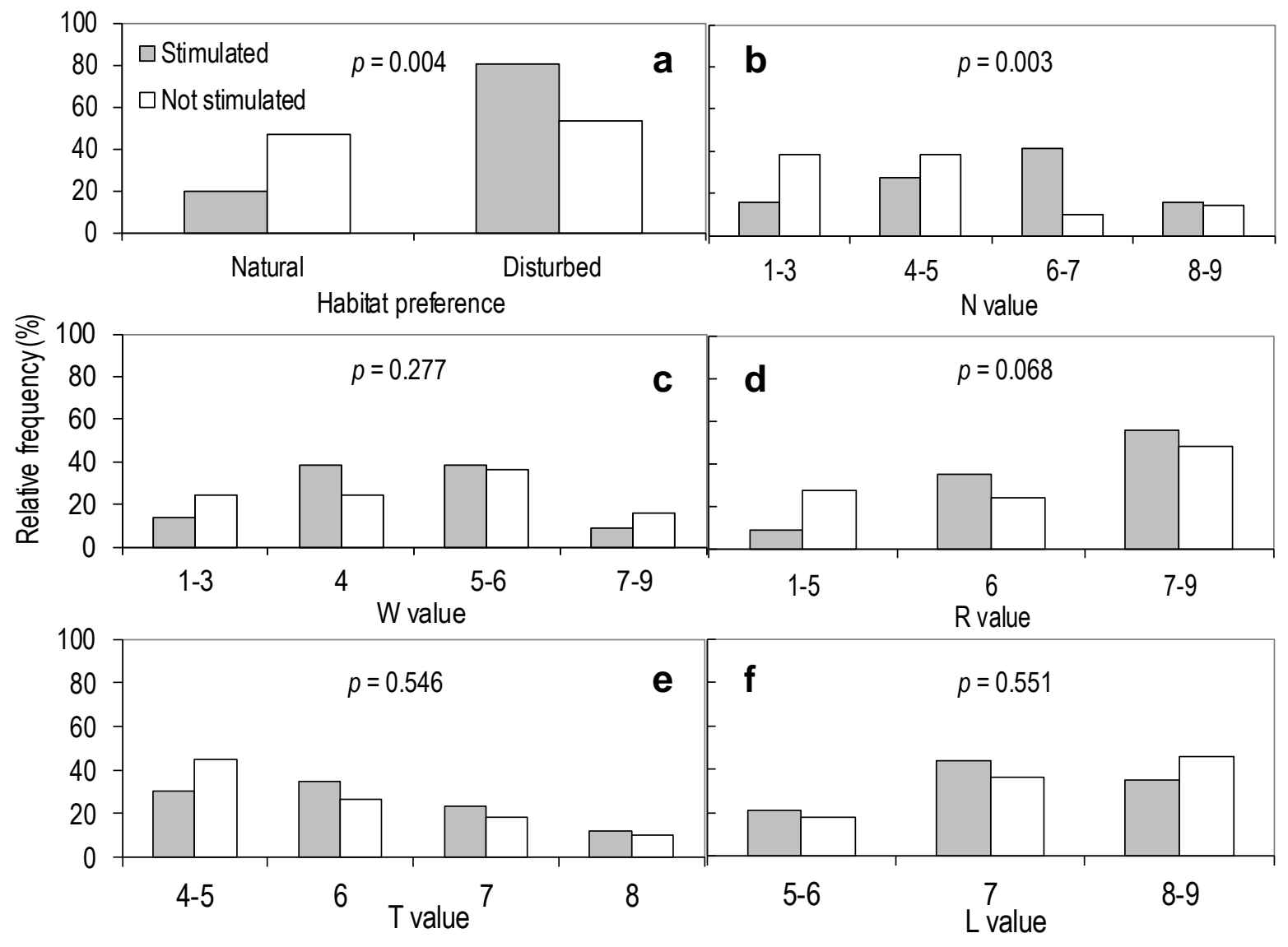

197 Figure 1. Frequency distributions of smoke-responsive (Stimulated) and non-responsive (Not

198 stimulated) species in the Hungarian flora according to a. habitat preferences $(\mathrm{n}=97)$, and

199 relative requirements for $\mathbf{b}$. soil nitrogen $(\mathrm{N}, \mathrm{n}=94)$, c. soil moisture $(\mathrm{W}, \mathrm{n}=94)$, d. soil 200 reaction $(R, n=93)$, e. habitat temperature regime $(T, n=92)$ and $\mathbf{f}$. light $(L, n=93)$. Species 201 preferring natural habitats are unique or rare, strictly protected, protected, dominant native, 202 accessorial native or natural pioneer species of natural plant communities; species associated 203 with disturbed habitats include disturbance tolerant native, adventive, cultivated or weed 204 species. $\mathrm{N}$ values range from 1 (plants on soils extremely poor in mineral nitrogen) to 9 205 (plants on over-fertilized soils, extremely rich in nitrogen on a range of $\mathrm{N}$ contents typical for 206 European soils). W values range from 1 (plants of extreme arid habitats) to 12 (submersed 207 aquatic plants). R values range from 1 (extremely acidophilic, calcifuge plants) to 9 (calcicole 208 plants, basophilic specialists). T values range from 1 (plants of subnival or supraboreal zone) 209 to 9 (plants of the Eumediterranean evergreen zone). L values range from 1 (full shade plants) 
to 9 (full-sun plants of open habitats). The $p$ values show the results of Chi-square tests of

211 homogeneity.

213 Among the life history traits analyzed in this study (life form and seed properties) the 214 distribution of Raunkiaer life forms was most varied between the two species groups differing 215 in germination response to smoke. The majority $(67 \%)$ of smoke-responsive species were 216 annuals or biennials, whereas the proportion of species lacking germination enhancement in 217 response to smoke of these life forms and that of perennial herbs were the same (43\% each; 218 Fig. 2a).
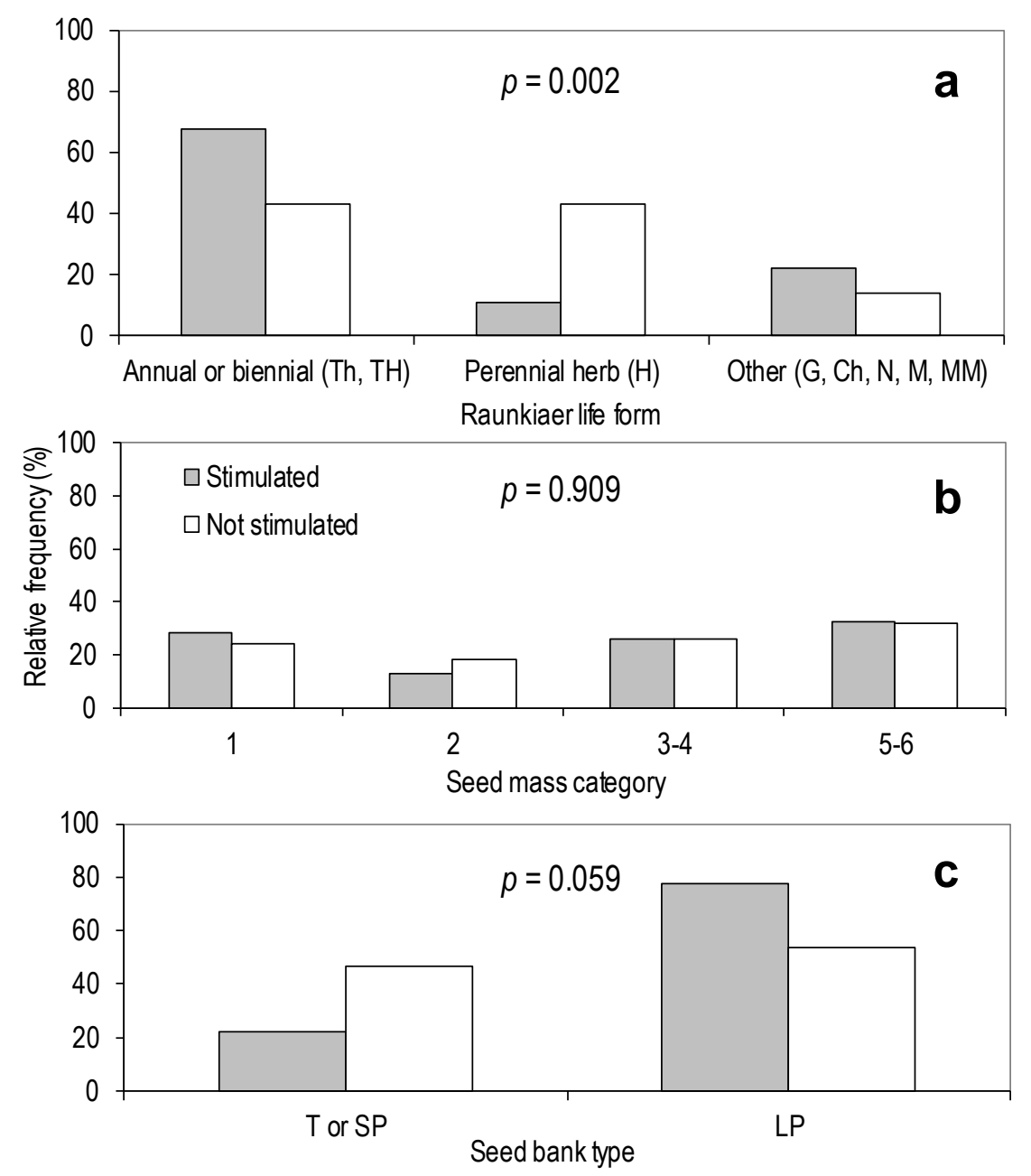

220 Figure 2. Frequency distributions of smoke-responsive (Stimulated) and non-responsive (Not 221 stimulated) species in the Hungarian flora according to a. Raunkiaer life forms $(\mathrm{n}=97)$, b. 
seed mass categories $(n=96)$ and $\mathbf{c}$. seed bank types $(n=55)$. Life forms: therophytes $(T h)$;

223 hemitherophytes (TH); hemicryptophytes (H); geophytes (G); chamaephytes (Ch);

224 nanophanerophytes (N); microphanerophytes (M); mega-mesophanerophytes (MM). Seed 225 mass categories: $1: \leq 0.2 \mathrm{~g} ; 2: 0.21-0.50 \mathrm{~g} ; 3: 0.51-1 \mathrm{~g} ; 4: 1.01-2 \mathrm{~g} ; 5: 2.01-10 \mathrm{~g} ; 6: \geq 10.01$ 226 g). Seed bank types: transient (T); short-term persistent (SP); long-term persistent (LP). The $p$ 227 values show the results of Chi-square tests of homogeneity.

229 Mean thousand-seed mass and seed shape (expressed as the extent to which shape differs 230 from sphericity) did not differ significantly between the two types of germination, despite the 2312.5 -fold greater variance of seed dimensions for species non-responsive to smoke (Table 1). 232 Consistent with this, no significant difference was found in the distribution of species 233 according to seed mass categories between the two species groups (Fig. 2b). However, long234 term persistence tended to be more frequent (78\%) than the transient and short-term persistent 235 seed bank types together (22\%) for species with smoke-stimulated germination, while for 236 species non-responsive to smoke, the proportions of the two seed bank categories were similar 237 (54\% and 46\%, respectively; Fig. 2c). Most of the species with long-term persistent seed bank 238 were characteristic of disturbed habitats (weeds, disturbance tolerant natives or adventive 239 species) in both the smoke-responsive group (86\%) and the group non-responsive to smoke 240 (80\%; Appendix A).

\begin{tabular}{lccc}
\hline Seed trait & Stimulated & Not stimulated & $\boldsymbol{p}$ value \\
\hline TSM & $3.09 \pm 0.85(44)$ & $2.04 \pm 0.57(49)$ & 0.524 \\
$\begin{array}{l}\text { Variance of seed } \\
\text { dimensions }\end{array}$ & $0.97 \pm 0.25(38)$ & $2.43 \pm 0.85(46)$ & 0.222 \\
\hline
\end{tabular}

243 Table 1. Thousand-seed mass (TSM; g) and the variance of three seed dimensions 244 (transformed so that width is unity) for species in the Hungarian flora that are smoke- 
responsive (Stimulated) or non-responsive (Not stimulated). Mean values $\pm 1 \mathrm{SE}$. The

246 numbers of species are indicated in parentheses. The $p$ values show the results of two-sample

247 t-tests. Quercus robur with its extremely high value was excluded from TSM.

\section{Discussion}

Among the eleven plant traits studied, only one life history and two habitat characteristics showed significant differences between the species group that displayed a positive germination response to smoke and the group which did not. These results suggest that

smoke-stimulated germination is associated with only a small number of distinctive plant traits for species from a semiarid temperate region of Europe, and in concert with previous

256 findings, support the widespread occurrence of positive germination response to smoke across a variety of life history traits (Brown et al. 2003; Dixon et al. 1995) and habitats (Crosti et al. 2006; Dixon et al. 2009).

The different distribution patterns of the degree of disturbance and the relative nitrogen

260 level of the habitat for the two germination response groups are consistent with our hypothesis $261\left(\mathrm{H}_{1}\right)$ that habitat conditions favouring smoke-stimulated germination should be different from 262 those preferred by the species not displaying a positive germination response to smoke. As expected, species indicating habitat disturbance, including a large number of weeds, were 264 prevalent in the species group which showed improved germination in response to smoke. A 265 possible explanation for this is that rather than being a natural disturbance factor (i.e. 266 wildfires), fires have frequently been associated with human activities (particularly with land use) in the Hungarian vegetation (Deák et al. 2014; Feurdean et al. 2012). Similar to other

268 disturbances (such as livestock grazing or ploughing), fire also eliminates aboveground 269 vegetation, reduces competition, increases temperature and light at the soil surface, reduces 
soil moisture and can elevate soil nitrate levels (Baskin and Baskin 1998). In such

271 circumstances, species which can tolerate and utilize the altered, post-fire environment are

272 most likely to be weeds responding to human disturbances. Smoke may function as a signal

273 for these weedy species indicating that conditions are suitable for seedling establishment. An

274 increased abundance of weeds was observed in several grasslands of Hungary after fire (Deák

275 et al. 2014). In Australia, weeds appeared to be highly responsive to the application of smoke-

276 water in a disturbed forest (Ruthrof et al. 2011) and to that of karrikinolide in agroecosystems

277 (Stevens et al. 2007). In our study, the high proportion of species associated with soils rich or

278 moderately rich in nitrogen among the smoke-responsive species is in accordance with the

279 predominance of weeds in this species group. Fire can increase the level of soil ammonium or

280 nitrate (Baskin and Baskin 1998; Certini 2005), which might be conducive to the

281 establishment of nitrophilous weeds. Weed species favouring high nitrogen availability

282 invaded the burnt area during early succession following a large wildfire in a Picea abies

283 forest of the Tatra Mountains (Šoltés et al. 2010). In contrast, numerous smoke-responsive

284 species are characteristic to nutrient poor habitats in South Africa (Brown et al. 2003) and

285 Australia (Dixon et al. 1995).

286 Among the life history traits studied, life form appeared to be a reliable predictor of the 287 germination response to smoke for species belonging to the Hungarian flora. Predominantly 288 annual or biennial species displayed smoke-enhanced germination and this is in line with our 289 predictions based on the frequently reported positive response of short-lived species to 290 disturbance (Belsky 1992; Ghermandi et al. 2004; Török et al. 2008). At the same time, our 291 result may suggest that smoke is a more important germination signal for species regenerating 292 mainly or exclusively from seeds, than for perennials, most of which are capable of 293 maintaining their populations by resprouting from vegetative organs after fire. In fire-prone 294 Mediterranean ecosystems, the life forms that appeared to be the most responsive to smoke 
were annuals (Keeley and Bond 1997; Tormo et al. 2014) or herbaceous perennials (Brown et

296 al. 2003). However, the lack of significant differences in seed properties between the species 297 groups which displayed or did not display enhanced germination in response to smoke does not support the hypothesis $\left(\mathrm{H}_{2}\right)$ that smoke-stimulated germination should be associated with specific regeneration-related life history traits. Similar seed shape in the two species groups may possibly be explained by the dual (stimulatory vs. inhibitory) effect of smoke on 301 germination depending on the exposure time and the concentration of smoke solution (Light 302 et al. 2002). At low concentration, species having larger seed surface area (i.e. more slender or flatter seeds) may benefit from more contact with smoke-water, but a higher concentration of smoke solution or prolonged exposure to smoke(-water) might cause greater reduction in the germination of such species. Tsuyuzaki and Miyoshi (2009) tested 40 species in a cool temperate zone of northern Japan, and found that the germination of slender seeds diminished more than that of round seeds after exposure to aerosol smoke. In line with our results, in other studies on 18-61 species from fire-prone or fire-free environments there was no relationship between seed mass and the effect of smoke on seed germination percentage 310 (Abella 2009; Daws et al. 2007; Tsuyuzaki and Miyoshi 2009). It is possible that other seed 311 traits, such as seed coat thickness (Adkins and Peters 2001) and/or seed dormancy status (for species that require dormancy alleviation before becoming smoke-responsive: e.g. Baker et al.

313 2005) may play more important role in determining the germination response to smoke than 314 seed mass and shape. In our study, a possible explanation for the lack of significant difference 315 in seed bank types between the two germination response groups can be that smoke316 responsive species in the Hungarian flora are not typical fire-recruiters with persistent soil317 stored seed banks (in contrast to certain fire-prone regions (e.g. Californian chaparral: Keeley 318 1991; Keeley and Bond 1997), where fire-recruiters are abundant). Irrespective of 319 germination response to smoke, at least $80 \%$ of the species with long-term persistent seed 
banks were weedy, disturbance tolerant native or adventive species. Thus, the tendency for

321 higher frequency of long-term persistence among the smoke-responsive species may be due to

322 the greater proportion of species associated with disturbed habitats in this group (see Figs. 1a

323 and 2c). Consistent with this pattern, Thompson et al. (1998) reported higher seed persistence

324 with increasing habitat disturbance for a large set of the north-west European flora.

325 In conclusion, in this examination of a subset of the Hungarian flora, a few but marked

326 differences in life history and habitat traits between the two species groups differing in

327 germination response to smoke indicate a frequent occurrence of smoke-stimulated

328 germination among annual or biennial, nitrophilous or disturbance tolerant species, which

329 often maintain long-term persistent seed banks. This knowledge can potentially assist in more

330 efficient vegetation restoration (Read et al. 2000; Ruthrof et al. 2011) or weed control

331 (Adkins and Peters 2001; Dixon et al. 2009; Kulkarni et al. 2011). Our study also highlights

332 the need for further research involving a greater number of species to confirm our results and

333 make generalizations about the relationships between the germination response to smoke and

334 specific plant traits for the European semiarid temperate flora.

\section{References}

338 Abella S.R. (2009) Smoke-cued emergence in plant species of ponderosa pine forests:

339 contrasting greenhouse and field results. Fire Ecol, 5, 22-37.

340 Adkins S.W., Peters N.C.B. (2001) Smoke derived from burnt vegetation stimulates 341 germination of arable weeds. Seed Sci Res, 11, 213-222.

342 Baker K.S., Steadman K.J., Plummer J.A., Merritt D.J., Dixon K.W. (2005) The changing 343 window of conditions that promotes germination of two fire ephemerals, Actinotus 

1236.

346 Baskin C.C., Baskin J.M. (1988) Germination ecophysiology of herbaceous plant species in a 347 temperate region. Am J Bot, 75, 286-305.

348 Baskin C.C., Baskin J.M. (1998) Seeds: ecology, biogeography, and evolution of dormancy 349 and germination. Academic Press, San Diego, California, USA.

350 Belsky A.J. (1992) Effects of grazing, competition, disturbance and fire on species 351 composition and diversity in grassland communities. J Veg Sci, 3, 187-200.

352 Borhidi A. (1995) Social behaviour types, the naturalness and relative ecological indicator 353 values of the higher plants in the Hungarian flora. Acta Bot Hung, 39, 97-181.

354 Brown N.A.C., Van Staden J., Johnson T., Daws M.I. (2003) A summary of patterns in the 355 seed germination response to smoke in plants from the Cape Floral Region. In: Smith R.D., 356 Dickie J.B., Linnington S.H., Pritchard H.W., Probert R.J. (Eds), Seed conservation: 357 Turning science into practice. Royal Botanic Gardens, Kew; London, UK, pp. 563-574. 358 Certini G. (2005) Effects of fire on properties of forest soils: a review. Oecologia, 143, 1-10.

359 Crosti R., Ladd P.G., Dixon K.W., Piotto B. (2006) Post-fire germination: The effect of 360 smoke on seeds of selected species from the central Mediterranean basin. For Ecol Manag, $361 \quad 221,306-312$.

362 Daws M.I., Davies J., Pritchard H.W., Brown N.A.C., Van Staden J. (2007) Butenolide from 363 plant-derived smoke enhances germination and seedling growth of arable weed species. $364 \quad$ Plant Growth Regul, 51, 73-82.

365 Deák B., Valkó O., Török P., Végvári Zs., Hartel T., Schmotzer A., Kapocsi I., Tóthmérész B. 366 (2014) Grassland fires in Hungary - Experiences of nature conservationists on the effects of 367 fire on biodiveristy. Appl Ecol Environ Res, 12, 267-283. 
De Lange J.H., Boucher C. (1990) Autecological studies on Audouinia capitata (Bruniaceae).

369 I. Plant-derived smoke as a seed germination cue. S Afr J Bot, 56, 700-703.

370 Dixon K.W., Merritt D.J., Flematti G.R., Ghisalberti E.L. (2009) Karrikinolide - a

371 phytoreactive compound derived from smoke with applications in horticulture, ecological

372 restoration and agriculture. Acta Hortic, 813, 155-170.

373 Dixon K.W., Roche S., Pate J.S. (1995) The promotive effect of smoke derived from burnt 374 native vegetation on seed germination of Western Australian plants. Oecologia, 101, 185375192.

376 Feurdean A., Spessa A., Magyari E.K., Willis K.J., Veres D., Hickler T. (2012) Trends in 377 biomass burning in the Carpathian region over the last 15,000 years. Quat Sci Rev, 45, 111$378 \quad 125$.

379 Flematti G.R., Ghisalberti E.L., Dixon K.W., Trengove R.D. (2009) Identification of alkyl 380 substituted $2 \mathrm{H}$-furo[2,3-c]pyran-2-ones as germination stimulants present in smoke. J Agric $381 \quad$ Food Chem, 57, 9475-9480.

382 Ghermandi L., Guthmann N., Bran D. (2004) Early post-fire succession in northwestern 383 Patagonia grasslands. J Veg Sci, 15, 67-76.

384 Goldammer J.G., Bruce M. (2004) The use of prescribed fire in the land management of 385 Western and Baltic Europe: an overview. Int For Fire News, 30, 2-13.

386 Hodgson J.G., Grime J.P., Hunt R., Thompson K. (1995) The electronic comparative plant 387 ecology. Chapman \& Hall, London, UK.

388 Keeley J.E. (1991) Seed germination and life history syndromes in the California chaparral. 389 The Bot Rev, 57, 81-116.

390 Keeley J.E., Bond W.J. (1997) Convergent seed germination in South African fynbos and 391 Californian chaparral. Plant Ecol, 133, 153-167. 
392 Király G. (Ed) (2009) Új magyar füvészkönyv. Magyarország hajtásos növényei. 393 Határozókulcsok. [The vascular plants of Hungary. Identification key.] Aggteleki Nemzeti 394 Park Igazgatóság, Jósvafő, Hungary (in Hungarian).

395 Kulkarni M.G., Light M.E., Van Staden J. (2011) Plant-derived smoke: Old technology with 396 possibilities for economic applications in agriculture and horticulture. S Afr J Bot, 77, 972397979.

398 Light M.E., Gardner M.J., Jäger A.K., Van Staden J. (2002) Dual regulation of seed 399 germination by smoke solutions. Plant Growth Regul, 37, 135-141.

400 Long R.L., Stevens J.C., Griffiths E.M., Adamek M., Gorecki M.J., Powles S.B., Merritt D.J. 401 (2011) Seeds of Brassicaceae weeds have an inherent or inducible response to the 402 germination stimulant karrikinolide. Ann Bot, 108, 933-944.

403 Merritt D.J., Kristiansen M., Flematti G.R., Turner S.R., Ghisalberti E.L., Trengove R.D., 404 Dixon, KW (2006) Effects of a butenolide present in smoke on light-mediated germination 405 of Australian Asteraceae. Seed Sci Res, 16, 29-35.

406 Mojzes A., Kalapos T. (2014) Plant-derived smoke stimulates germination of four herbaceous 407 species common in temperate regions of Europe. Plant Ecol, 215, 411-415.

408 Moreira B., Tormo J., Estrelles E., Pausas J.G. (2010) Disentangling the role of heat and 409 smoke as germination cues in Mediterranean Basin flora. Ann Bot, 105, 627-635.

410 Niklasson M., Zin E., Zielonka T., Feijen M., Korczyk A.F., Churski M., Samojlik T., 411 Jędrzejewska B., Gutowski J.M., Brzeziecki B. (2010) A 350-year tree-ring fire record from 412 Białowieża Primeval Forest, Poland: implications for Central European lowland fire history. $413 \quad J$ Ecol, 98, 1319-1329.

414 Pechony O., Shindell D.T. (2010) Driving forces of global wildfires over the past millennium 415 and the forthcoming century. Proc Natl Acad Sci USA, 107, 19167-19170. 
416 Pierce S.M., Esler K., Cowling R.M. (1995) Smoke-induced germination of succulents

417 (Mesembryanthemaceae) from fire-prone and fire-free habitats in South Africa. Oecologia, $418 \quad \mathbf{1 0 2}, 520-522$.

419 Quinn G.P., Keough M.J. (2002) Experimental design and data analysis for biologists. 420 Cambridge University Press, New York, USA.

421 Read T.R., Bellairs S.M., Mulligan D.R., Lamb D. (2000) Smoke and heat effects on soil seed 422 bank germination for the re-establishment of a native forest community in New South $423 \quad$ Wales. Austral Ecol, 25, 48-57.

424 Ruthrof K.X., Calver M.C., Dell B., Hardy G.E.St.J. (2011) Look before planting: using 425 smokewater as an inventory tool to predict the soil seed bank and inform ecological 426 management and restoration. Ecol Manag Restor, 12, 154-157.

427 Schermann Sz. (1967) Magismeret I-II. [Handbook of seeds, vols. I-II]. Akadémiai Kiadó, 428 Budapest, Hungary (in Hungarian).

429 Schütz W. (2000) Ecology of seed dormancy and germination in sedges (Carex). Perspect $430 \quad$ Plant Ecol Evol Syst, 3, 67-89.

431 Simon T. (1988) A hazai edényes flóra természetvédelmi-érték besorolása. [Nature 432 conservation ranks of the Hungarian vascular flora.] Abstr Bot, 12, 1-23.

433 Soó R. (1964-1985) A Magyar flóra és vegetáció rendszertani-növényföldrajzi kézikönyve I434 VII. [Synopsis systematico-geobotanica florae vegetationisque Hungariae, vols. I-VII]. 435 Akadémiai Kiadó, Budapest, Hungary (in Hungarian).

436 Stevens J.C., Merritt D.J., Flematti G.R., Ghisalberti E.L., Dixon K.W. (2007) Seed 437 germination of agricultural weeds is promoted by the butenolide 3 -methyl- $2 \mathrm{H}$-furo[2,3$438 \quad c$ ]pyran-2-one under laboratory and field conditions. Plant Soil, 298, 113-124. 
439 Šoltés R., Školek J., Homolová Z., Kyselová Z. (2010) Early successional pathways in the

440 Tatra Mountains (Slovakia) forest ecosystems following natural disturbances. Biologia, $\mathbf{6 5}$, $441958-964$.

442 The International Plant Names Index (2012) Published on the Internet: http://www.ipni.org. 443 (last accessed 15 April 2014).

444 Thompson K., Bakker J.P., Bekker R.M. (1997) The soil seed banks of North West Europe: 445 methodology, density and longevity. Cambridge University Press, Cambridge, UK.

446 Thompson K., Bakker J.P., Bekker R.M., Hodgson J.G. (1998) Ecological correlates of seed 447 persistence in soil in the north-west European flora. J Ecol, 86, 163-169.

448 Thompson K., Band S.R., Hodgson J.G. (1993) Seed size and shape predict persistence in 449 soil. Funct Ecol, 7, 236-241.

450 Thompson K., Grime J.P., Mason G. (1977) Seed germination in response to diurnal 451 fluctuations of temperature. Nature, 267, 147-149.

452 Tormo J., Moreira B., Pausas J.G. (2014) Field evidence of smoke-stimulated seedling 453 emergence and establishment in Mediterranean Basin flora. J Veg Sci, 25, 771-777.

454 Török P., Matus G., Papp M., Tóthmérész B. (2008) Secondary succession in overgrazed 455 Pannonian sandy grasslands. Preslia, 80, 73-85.

456 Tsuyuzaki S., Miyoshi C. (2009) Effects of smoke, heat, darkness and cold stratification on 457 seed germination of 40 species in a cool temperate zone in northern Japan. Plant Biol, 11, $458 \quad 369-378$. 
Appendix A. Germination response to smoke treatment, seed properties, life form and habitat requirements for the species involved in the analysis. Abbreviations: Smoke - seed

461 germination is stimulated (+) or not stimulated (-) by aerosol smoke, smoke-water or 462 karrikinolide treatment; Ref. - literature sources of the species' smoke response data (0 463 indicates Mojzes and Kalapos unpublished results assessed by the same protocol as 464 described in Mojzes and Kalapos (2014); Var. - the variance of three seed dimensions 465 (length, width and thickness, transformed so that width is unity); TSM (g) - thousand-seed mass expressed in grams; Mass categ. - seed mass category $(1: \leq 0.2 \mathrm{~g} ; 2$ : $0.21-0.50 \mathrm{~g} ; 3$ : 0.51-1 g; 4: 1.01-2 g; 5: 2.01-10 g; 6: $\geq 10.01 \mathrm{~g}$ ); Bank - seed bank type (T: transient; SP: short-term persistent; LP: long-term persistent); Life form - Raunkiaer life form (Th: therophyte; TH: hemitherophyte; H: hemicryptophyte; G: geophyte; Ch: chamaephyte; N: nanophanerophyte; M: microphanerophyte; MM: mega-mesophanerophyte); Habitat habitat preference (Species preferring natural habitats are unique or rare (U), strictly 472 protected (SP), protected (P), dominant native (DN), accessorial native (AN) and natural 473 pioneer (NP) species. Species associated with disturbed habitats include disturbance tolerant 474 native (DT), adventive (A), cultivated (C) and weed (W) species.); $\mathrm{N}$ - nitrogen requirement 475 from 1 (plants on soils extremely poor in mineral nitrogen) to 9 (plants on over-fertilized soils, extremely rich in nitrogen); $\mathrm{W}$ - soil moisture requirement from 1 (plants of extreme 477 arid habitats) to 12 (submersed aquatic plants); $\mathrm{R}$ - soil reaction requirement from 1 478 (extremely acidophilic, calcifuge plants) to 9 (calcicole plants, basophilic specialists); $\mathrm{T}$ 479 temperature requirement from 1 (plants of subnival or supraboreal zone) to 9 (plants of the 480 Eumediterranean evergreen zone) and L - light requirement from 1 (full shade plants) to 9 481 (full-sun plants of open habitats). Nomenclature follows the source published papers. 482 Asterisks indicate species that are not native to Hungary (Király 2009). 


\begin{tabular}{|c|c|c|c|c|c|c|c|c|c|c|c|c|c|c|}
\hline Species & Family & Smoke & Ref. & Var. & TSM & Mass categ. & Bank & Life form & Habitat & $\mathrm{N}$ & $\mathrm{W}$ & $\mathrm{R}$ & & $\mathrm{L}$ \\
\hline Achillea millefolium & Asteraceae & - & 12 & 1.38 & 0.12 & 1 & $\mathrm{~T}$ & $\mathrm{H}$ & DT & 5 & 6 & 5 & & 8 \\
\hline Alnus glutinosa & Betulaceae & + & 8 & 0.36 & 1.00 & 3 & SP & MM-M & $\mathrm{DN}$ & 7 & 9 & 6 & 5 & 5 \\
\hline Alopecurus myosuroides* & Poaceae & + & 3 & 1.27 & 2.05 & 5 & & $\mathrm{Th}$ & $\mathrm{W}$ & 7 & 6 & 7 & 6 & 7 \\
\hline Anagallis arvensis & Primulaceae & + & 25 & 0.15 & 0.55 & 3 & LP & Th & $\mathrm{W}$ & 6 & 4 & 7 & 6 & 6 \\
\hline Angelica sylvestris & Apiaceae & - & 3 & 0.27 & 1.50 & 4 & LP & $\mathrm{H}$ & AN & 6 & 8 & 6 & 6 & 7 \\
\hline Anthriscus caucalis & Apiaceae & + & 12 & 2.17 & 0.95 & 3 & & Th & $\mathrm{W}$ & 8 & 5 & 6 & 7 & 7 \\
\hline Anthyllis vulneraria & Fabaceae & - & 28 & 0.22 & 2.33 & 5 & SP & $\mathrm{H}$ & AN & 4 & 4 & 7 & 6 & 8 \\
\hline Aphanes arvensis & Rosaceae & - & 12,13 & 0.30 & 0.18 & 1 & LP & $\mathrm{Th}$ & $\mathrm{W}$ & 5 & 6 & 5 & 6 & 6 \\
\hline Arabidopsis thaliana & Brassicaceae & + & 22 & 0.46 & 0.02 & 1 & LP & Th-TH & $\mathrm{NP}$ & 4 & 4 & 7 & 6 & 6 \\
\hline Asclepias syriaca* & Apocynaceae & + & 0 & 0.49 & 5.53 & 5 & LP & $\mathrm{H}$ & $\mathrm{W}$ & 4 & 4 & 6 & 7 & 7 \\
\hline Astragalus cicer & Fabaceae & - & 2 & 0.20 & 2.55 & 5 & & $\mathrm{H}$ & AN & 3 & 4 & 7 & 6 & 7 \\
\hline Avena barbata* & Poaceae & + & 12 & & 11.70 & 6 & & Th & $\mathrm{W}$ & & & & & \\
\hline Avena fatua & Poaceae & + & $3,9,11,19,30$ & 5.54 & 30.00 & 6 & & Th & $\mathrm{W}$ & 4 & 5 & 7 & 7 & 7 \\
\hline Avena sterilis* & Poaceae & + & 3 & & 16.74 & 6 & & Th & $\mathrm{W}$ & & & & & \\
\hline Briza media & Poaceae & - & 29 & 0.25 & 0.54 & 3 & $\mathrm{~T}$ & $\mathrm{H}$ & AN & 3 & 6 & 5 & 5 & 8 \\
\hline Bromus diandrus* & Poaceae & + & 19 & & 10.66 & 6 & & Th & A & 3 & 2 & 8 & 8 & 8 \\
\hline Bromus sterilis & Poaceae & - & 9 & 27.93 & 7.80 & 5 & $\mathrm{~T}$ & Th & $\mathrm{W}$ & 5 & 4 & 6 & 7 & 7 \\
\hline Bromus tectorum & Poaceae & - & 9 & 10.93 & 3.05 & 5 & & Th & $\mathrm{NP}$ & 4 & 3 & 8 & 6 & 8 \\
\hline Calluna vulgaris & Ericaceae & + & 20 & 4.29 & 0.04 & 1 & LP & $\mathrm{Ch}(\mathrm{N})$ & AN & 1 & 5 & 1 & 3 & 8 \\
\hline Camelina microcarpa & Brassicaceae & + & 21 & 0.12 & 0.29 & 2 & $\mathrm{~T}$ & Th & $\mathrm{W}$ & 4 & 4 & 8 & 6 & 7 \\
\hline Capsella bursa-pastoris & Brassicaceae & + & 9,21 & 0.72 & 0.13 & 1 & LP & Th-TH & $\mathrm{W}$ & 7 & 5 & & 6 & 8 \\
\hline Cardamine hirsuta & Brassicaceae & - & 12 & & 0.09 & 1 & LP & Th-TH & DT & 7 & 5 & 5 & 6 & 6 \\
\hline Centaurium erythraea & Gentianaceae & - & 23 & 0.09 & 0.01 & 1 & SP & Th & AN & 5 & 5 & 6 & 6 & 8 \\
\hline Chamerion angustifolium & Onagraceae & - & 1,32 & 1.56 & 0.08 & 1 & & $\mathrm{H}$ & DT & 9 & 5 & 5 & 4 & 8 \\
\hline Chenopodium album & Amaranthaceae & + & 9 & 0.10 & 0.90 & 3 & LP & $\mathrm{Th}$ & $\mathrm{W}$ & 7 & 4 & 6 & 6 & 7 \\
\hline
\end{tabular}




\begin{tabular}{|c|c|c|c|c|c|c|c|c|c|c|c|c|c|c|}
\hline Species & Family & Smoke & Ref. & Var. & TSM & Mass categ. & Bank & Life form & Habitat & $\mathrm{N}$ & $\mathrm{W}$ & $\mathrm{R}$ & & $\mathrm{L}$ \\
\hline Clematis vitalba & Ranunculaceae & + & 8 & 0.25 & 1.35 & 4 & SP & $\mathrm{N}-\mathrm{E}$ & AN & 7 & 5 & 6 & 7 & 7 \\
\hline Conyza canadensis* & Asteraceae & + & 4 & 1.40 & 0.05 & 1 & SP & Th-TH & $\mathrm{W}$ & 4 & 4 & 6 & 6 & 8 \\
\hline Cynodon dactylon & Poaceae & - & 15 & 0.62 & 0.34 & 2 & & $\mathrm{G}(\mathrm{H})$ & DT & 5 & 3 & 7 & 7 & 8 \\
\hline Dactylis glomerata & Poaceae & + & 24 & 6.75 & 0.88 & 3 & SP & $\mathrm{H}$ & DT & 6 & 6 & 4 & 5 & 7 \\
\hline Danthonia decumbens & Poaceae & - & 29 & 1.05 & 0.87 & 3 & & $\mathrm{H}$ & AN & 2 & 5 & 5 & 5 & 8 \\
\hline Daucus carota & Apiaceae & + & 11 & 0.40 & 2.20 & 5 & LP & Th-TH & DT & 4 & 4 & 7 & 6 & 8 \\
\hline Descurainia sophia & Brassicaceae & + & 21 & 0.56 & 0.12 & 1 & & Th & $\mathrm{W}$ & 6 & 4 & 7 & 6 & 8 \\
\hline Digitaria ciliaris & Poaceae & - & 6 & & 0.59 & 3 & & Th & $\mathrm{W}$ & & & & & \\
\hline Drosera rotundifolia & Droseraceae & - & 32 & & 0.01 & 1 & & $\mathrm{H}$ & SP & 1 & 9 & 1 & 4 & 8 \\
\hline Echinochloa crus-galli & Poaceae & + & 17 & 0.39 & 2.00 & 4 & & $\mathrm{Th}$ & $\mathrm{W}$ & 8 & 7 & 7 & 7 & 8 \\
\hline Echium vulgare & Boraginaceae & - & 31 & 0.21 & 2.95 & 5 & & $\mathrm{TH}$ & NP & 4 & 3 & 6 & 7 & 9 \\
\hline Epilobium glandulosum & Onagraceae & - & 16 & 0.34 & 0.07 & 1 & & $\mathrm{H}$ & AN & 5 & 9 & 5 & 7 & 7 \\
\hline Eragrostis cilianensis & Poaceae & + & 25 & 0.01 & 0.14 & 1 & & Th & $\mathrm{W}$ & 3 & 3 & 6 & 7 & 7 \\
\hline Erodium cicutarium & Geraniaceae & - & 12,13 & 2.52 & 2.71 & 5 & LP & Th & $\mathrm{W}$ & 4 & 4 & 7 & 6 & 8 \\
\hline Euphorbia exigua & Euphorbiaceae & - & 31 & 0.21 & 0.51 & 3 & & $\mathrm{Th}$ & $\mathrm{W}$ & 4 & 4 & 8 & 6 & 6 \\
\hline Fallopia convolvulus & Polygonaceae & + & 3 & 0.16 & 4.00 & 5 & LP & Th & $\mathrm{W}$ & 3 & 5 & 5 & 5 & 7 \\
\hline Festuca idahoensis & Poaceae & - & 5 & & & & & $\mathrm{H}$ & $\mathrm{P}$ & 2 & 3 & 9 & 3 & 6 \\
\hline Fraxinus ornus & Oleaceae & - & 8 & 3.75 & 17.86 & 6 & & MM & $\mathrm{DN}$ & 3 & 3 & 8 & 8 & 5 \\
\hline Galium aparine & Rubiaceae & + & 3 & 0.02 & 6.70 & 5 & $\mathrm{~T}$ & Th & $\mathrm{W}$ & 9 & 7 & 6 & 5 & 7 \\
\hline Heracleum sphondylium & Apiaceae & - & 3 & 0.32 & 6.15 & 5 & $\mathrm{~T}$ & $\mathrm{H}$ & AN & 5 & 5 & 6 & 5 & 5 \\
\hline Holcus lanatus & Poaceae & - & 24,29 & 1.02 & 0.34 & 2 & LP & $\mathrm{H}(\mathrm{Ch})$ & AN & 4 & 6 & 6 & 5 & 7 \\
\hline Hypericum perforatum & Hypericaceae & - & 31 & 1.02 & 0.13 & 1 & LP & $\mathrm{H}$ & DT & 3 & 3 & 6 & 5 & 7 \\
\hline Hypochoeris radicata & Asteraceae & - & 7 & 22.02 & 0.55 & 3 & SP & $\mathrm{H}$ & AN & 3 & 4 & 4 & 5 & 8 \\
\hline Juncus bufonius & Juncaceae & - & 13 & 0.21 & 0.03 & 1 & LP & Th & $\mathrm{W}$ & 6 & 7 & 5 & 5 & 7 \\
\hline Juncus effusus & Juncaceae & - & 32 & 0.75 & 0.01 & 1 & LP & $\mathrm{H}$ & DT & 3 & 9 & 6 & 5 & 8 \\
\hline
\end{tabular}




\begin{tabular}{|c|c|c|c|c|c|c|c|c|c|c|c|c|c|c|}
\hline Species & Family & Smoke & Ref. & Var. & TSM & Mass categ. & Bank & Life form & Habitat & $\mathrm{N}$ & $\mathrm{W}$ & $\mathrm{R}$ & & $\mathrm{L}$ \\
\hline Lamium purpureum & Lamiaceae & - & 3 & 0.39 & 0.75 & 3 & LP & $\mathrm{Th}(\mathrm{H})$ & $\mathrm{W}$ & 6 & 5 & 7 & 5 & 7 \\
\hline Lathraea squamaria & Orobanchaceae & + & 10 & 0.03 & 0.64 & 3 & & G & AN & 6 & 6 & 6 & 5 & 3 \\
\hline Leontodon saxatilis & Asteraceae & - & 12,13 & & 0.44 & 2 & & TH-H & $\mathrm{A}$ & 5 & 7 & 6 & 7 & 8 \\
\hline Lepidium campestre & Brassicaceae & + & 0 & 0.33 & 2.35 & 5 & LP & Th & $\mathrm{W}$ & 6 & 4 & 8 & 6 & 9 \\
\hline Linum trigynum & Linaceae & - & 31 & 0.41 & 0.15 & 1 & & Th & NP & 1 & 5 & 4 & 7 & 8 \\
\hline Lotus corniculatus & Fabaceae & - & 32 & 0.06 & 1.10 & 4 & LP & $\mathrm{H}$ & DT & 2 & 4 & 7 & 5 & 7 \\
\hline Malva neglecta & Malvaceae & + & 3,9 & 0.17 & 2.30 & 5 & LP & Th-TH & $\mathrm{W}$ & 9 & 4 & 6 & 6 & 7 \\
\hline Matricaria matricarioides* & Asteraceae & - & 9 & 1.02 & 0.15 & 1 & LP & $\mathrm{Th}$ & $\mathrm{A}$ & 8 & 4 & 7 & 5 & 8 \\
\hline Melica ciliata & Poaceae & + & 28 & 1.48 & 0.46 & 2 & & $\mathrm{H}$ & AN & 2 & 1 & 7 & 7 & 9 \\
\hline Mercurialis aппиа & Euphorbiaceae & - & 3 & 0.12 & 2.20 & 5 & & $\mathrm{Th}$ & $\mathrm{W}$ & 8 & 4 & 7 & 7 & 7 \\
\hline Oenothera biennis* & Onagraceae & - & 32 & 0.30 & 0.45 & 2 & & $\mathrm{TH}$ & $\mathrm{W}$ & 4 & 3 & 8 & 7 & 9 \\
\hline Orobanche caryophyllacea & Orobanchaceae & + & 10 & & & 1 & & $\mathrm{G}$ & AN & 2 & 3 & 9 & 6 & 8 \\
\hline Orobanche cernua & Orobanchaceae & + & 10 & & 0.15 & 1 & & Th-G & $\mathrm{W}$ & 5 & 4 & 7 & 6 & 7 \\
\hline Orobanche minor & Orobanchaceae & + & 10 & & & 1 & & $\mathrm{G}$ & $\mathrm{W}$ & 6 & 6 & 6 & 8 & 7 \\
\hline Orobanche purpurea & Orobanchaceae & + & 10 & & 0.01 & 1 & & $\mathrm{G}$ & AN & 2 & 3 & 8 & 7 & 8 \\
\hline Orobanche ramosa & Orobanchaceae & + & 10 & 0.14 & 0.02 & 1 & & Th-G & $\mathrm{W}$ & 6 & 4 & 7 & 8 & 7 \\
\hline Papaver rhoeas & Papaveraceae & + & 9 & 0.27 & 0.09 & 1 & LP & Th & $\mathrm{W}$ & 4 & 4 & 7 & 7 & 6 \\
\hline Pinus nigra* & Pinaceae & - & 26 & 0.46 & 20.60 & 6 & & MM & $\mathrm{C}$ & 2 & 4 & 9 & 8 & 7 \\
\hline Pinus sylvestris & Pinaceae & - & 26 & 0.89 & 5.50 & 5 & & $\mathrm{MM}$ & $\mathrm{AN}(\mathrm{C})$ & 2 & 4 & 5 & 4 & 7 \\
\hline Plantago lanceolata & Plantaginaceae & + & 21 & 0.50 & 1.25 & 4 & LP & $\mathrm{H}$ & DT(AN) & 5 & 4 & 6 & 5 & 7 \\
\hline Plantago media & Plantaginaceae & - & 21 & 0.49 & 0.26 & 2 & & $\mathrm{H}$ & DT & 3 & 5 & 7 & 5 & 7 \\
\hline Роа аппиа & Poaceae & + & 13 & 2.16 & 0.27 & 2 & LP & Th-TH & $\mathrm{W}$ & 8 & 6 & 6 & 5 & 7 \\
\hline Polygonum aviculare & Polygonaceae & + & 3 & & 1.70 & 4 & LP & Th & $\mathrm{W}$ & 5 & 4 & 6 & 5 & 9 \\
\hline Polygonum persicaria & Polygonaceae & + & 3 & 0.24 & 1.60 & 4 & LP & $\mathrm{Th}$ & $\mathrm{W}$ & 7 & 7 & 6 & 5 & 6 \\
\hline Potentilla recta & Rosaceae & - & 0 & 0.21 & 0.40 & 2 & SP & $\mathrm{H}$ & AN & 1 & 3 & 7 & 8 & 9 \\
\hline
\end{tabular}




\begin{tabular}{|c|c|c|c|c|c|c|c|c|c|c|c|c|c|c|}
\hline Species & Family & Smoke & Ref. & Var. & TSM & Mass categ. & Bank & Life form & Habitat & $\mathrm{N}$ & $\mathrm{W}$ & $\mathrm{R}$ & $\mathrm{T}$ & $\mathrm{L}$ \\
\hline Quercus robur & Fagaceae & - & 27 & 0.33 & 2500.00 & 6 & $\mathrm{~T}$ & MM-M & $\mathrm{DN}$ & 4 & 6 & 6 & 6 & 6 \\
\hline Raphanus raphanistrum & Brassicaceae & + & 18,30 & 0.09 & 13.60 & 6 & LP & Th & $\mathrm{W}$ & 5 & 5 & 5 & 5 & 6 \\
\hline Rubus caesius & Rosaceae & - & 33 & 0.55 & 3.40 & 5 & SP & $\mathrm{H}-\mathrm{N}$ & DT & 9 & 7 & 7 & 5 & 7 \\
\hline Rudbeckia hirta* & Asteraceae & - & 16 & 2.26 & 0.39 & 2 & & Th-TH & $\mathrm{C}$ & 5 & 8 & 8 & 7 & 8 \\
\hline Rumex acetosella & Polygonaceae & - & 14,32 & 0.02 & 0.35 & 2 & LP & $\mathrm{H}(\mathrm{G})$ & AN & 2 & 2 & 4 & 5 & 8 \\
\hline Rumex obtusifolius & Polygonaceae & - & 9 & 0.08 & 2.20 & 5 & LP & $\mathrm{H}$ & DT & 9 & 6 & 7 & 5 & 7 \\
\hline Senecio jacobaea & Asteraceae & + & 9,24 & 1.56 & 0.22 & 2 & LP & $\mathrm{H}$ & AN & 5 & 3 & 7 & 5 & 8 \\
\hline Sherardia arvensis & Rubiaceae & - & 31 & 0.44 & 1.95 & 4 & SP & Th & $\mathrm{W}$ & 5 & 5 & 8 & 6 & 6 \\
\hline Sinapis alba* & Brassicaceae & + & 9 & 0.01 & 3.95 & 5 & & Th & $\mathrm{W}$ & 6 & 4 & 8 & 7 & 8 \\
\hline Sinapis arvensis & Brassicaceae & - & 3 & 0.00 & 2.10 & 5 & LP & $\mathrm{Th}$ & $\mathrm{W}$ & 6 & 4 & 8 & 5 & 7 \\
\hline Sisymbrium orientale & Brassicaceae & + & $18,30,0$ & 0.68 & 0.12 & 1 & & Th-TH & $\mathrm{W}$ & 6 & 5 & 7 & 8 & 8 \\
\hline Solanum nigrum & Solanaceae & - & 25 & 0.36 & 0.90 & 3 & & $\mathrm{Th}$ & $\mathrm{W}$ & 8 & 6 & 7 & 6 & 7 \\
\hline Solidago virgaurea & Asteraceae & - & 32 & 2.86 & 0.61 & 3 & $\mathrm{~T}$ & $\mathrm{H}$ & AN & 5 & 5 & 6 & 5 & 5 \\
\hline Sonchus oleraceus & Asteraceae & + & 7 & 1.91 & 0.25 & 2 & LP & Th & $\mathrm{W}$ & 8 & 5 & 8 & 5 & 7 \\
\hline Sorghum halepense* & Poaceae & + & 3,9 & 1.40 & 4.50 & 5 & & $\mathrm{G}(\mathrm{H})$ & $\mathrm{C}$ & 7 & 6 & 7 & 8 & 7 \\
\hline Stellaria media & Caryophyllaceae & + & 9 & 0.04 & 0.45 & 2 & LP & Th-TH & $\mathrm{W}$ & 8 & 5 & 7 & 5 & 6 \\
\hline Taeniatherum caput-medusae & Poaceae & - & 5 & 5.75 & 2.96 & 5 & & Th & $\mathrm{NP}$ & 2 & 2 & 8 & 8 & 9 \\
\hline Thlaspi montanum & Brassicaceae & - & 1 & 0.20 & 0.65 & 3 & & $\mathrm{Ch}$ & $\mathrm{U}$ & 2 & 2 & 9 & 5 & 8 \\
\hline Urtica urens & Urticaceae & - & 12 & 0.36 & 0.50 & 2 & LP & Th & $\mathrm{W}$ & 8 & 5 & 6 & 6 & 7 \\
\hline Veronica hederifolia & Plantaginaceae & + & 3 & 0.13 & 3.55 & 5 & LP & Th & DT & 7 & 4 & 7 & 6 & 6 \\
\hline Veronica persica* & Plantaginaceae & + & 3 & 0.18 & 0.69 & 3 & LP & Th & $\mathrm{W}$ & 7 & 5 & 7 & 6 & 6 \\
\hline Vulpia bromoides & Poaceae & - & $7,12,13$ & 17.21 & 0.80 & 3 & $\mathrm{~T}$ & Th & NP & 2 & 2 & 3 & 8 & 9 \\
\hline
\end{tabular}


Appendix B. List of studies cited in Appendix A.

485

486 1. Abella S.R. (2009) Smoke-cued emergence in plant species of ponderosa pine forests: contrasting greenhouse and field results. Fire Ecol, 5, 22-37.

2. Abu Y., Romo J.T., Bai Y. (2013) Effects of plant derived smoke solutions on seed germination of forages. Soils and Crops Workshop Proceedings, Poster Presentations. 05-06.03.2013., University of Saskatchewan, Saskatoon, Saskatchewan, Canada: 3 pp.

3. Adkins S.W., Peters N.C.B. (2001) Smoke derived from burnt vegetation stimulates germination of arable weeds. Seed Sci Res, 11, 213-222.

4. Arán D., García-Duro J., Reyes O., Casal M. (2013) Fire and invasive species: Modifications in the germination potential of Acacia melanoxylon, Conyza canadensis and Eucalyptus globulus. For Ecol Manag, 302, 7-13.

5. Blank R.R., Young J.A. (1998) Heated substrate and smoke: Influence on seed emergence and plant growth. J Range Manag, 51, 577-583.

6. Chou Y-F., Cox R.D., Wester D.B. (2012) Smoke water and heat shock influence germination of shortgrass prairie species. Rangel Ecol Manag, 65, 260-267.

7. Coates T.D. (2003) The effect of concentrated smoke products on the restoration of highly disturbed mineral sands in southeast Victoria. Ecol Manag Restor, 4, 133-139.

8. Crosti R., Ladd P.G., Dixon K.W., Piotto B.

B. (2006) Post-fire germination: The effect of smoke on seeds of selected species from the central Mediterranean basin. For Ecol Manag, 221, 306-312.

9. Daws M.I., Davies J., Pritchard H.W., Brown N.A.C., Van Staden J. (2007) Butenolide from plant-derived smoke enhances germination and seedling growth of arable weed species. Plant Growth Regul, 51, 73-82. 
10. Daws M.I., Pritchard H.W., Van Staden J. (2008) Butenolide from plant-derived smoke functions as a strigolactone analogue: Evidence from parasitic weed seed germination. $S$ Afr J Bot, 74, 116-120.

11. Dixon K.W., Merritt D.J., Flematti G.R., Ghisalberti E.L. (2009) Karrikinolide - a phytoreactive compound derived from smoke with applications in horticulture, ecological restoration and agriculture. Acta Hortic, 813, 155-170.

12. Figueroa J.A., Cavieres L.A. (2012) The effect of heat and smoke on the emergence of exotic and native seedlings in a Mediterranean fire-free matorral of central Chile. Rev Chil de Hist Nat, 85, 101-111.

13. Figueroa J.A., Cavieres L.A., Gómez-González S., Molina Montenegro M., Jaksic F.M. (2009) Do heat and smoke increase emergence of exotic and native plants in the matorral of central Chile? Acta Oecol, 35, 335-340.

14. Franzese J., Ghermandi L. (2011) Seed longevity and fire: germination responses of an exotic perennial herb in NW Patagonian grasslands (Argentina). Plant Biol, 13, 865-871.

15. Ghebrehiwot H.M., Kulkarni M.G., Kirkman K.P., Van Staden J. (2012) Smoke and heat: influence on seedling emergence from the germinable soil seed bank of mesic grassland in South Africa. Plant Growth Regul, 66, 119-127.

16. Jefferson L.V., Pennacchio M., Havens K., Forsberg B., Sollenberger D., Ault J. (2008) Ex situ germination responses of Midwestern USA prairie species to plant derived smoke. Am Midl Nat, 159, 251-256.

17. Kamran M., Latif Khan A., Waqas M., Imran Q.M., Hamayun M., Kang S-M., Kim Y-H., Kim M-J., Lee I-J. (2014) Effects of plant-derived smoke on the growth dynamics of Science, 64, 121-128. 
532 18. Long R.L., Stevens J.C., Griffiths E.M., Adamek M., Gorecki M.J., Powles S.B., Merritt D.J. (2011a) Seeds of Brassicaceae weeds have an inherent or inducible response to the germination stimulant karrikinolide. Ann Bot, 108, 933-944.

19. Long R.L., Stevens J.C., Griffiths E.M., Adamek M., Powles S.B., Merritt D.J. (2011b) Detecting karrikinolide responses in seeds of the Poaceae. Aust J Bot, 59, 609-619.

20. Måren I.E., Janovský Z., Spindelböck J.P., Daws M.I., Kaland P.E., Vandvik V. (2010) Prescribed burning of northern heathlands: Calluna vulgaris germination cues and seed-

21. Mojzes A., Kalapos T. (2014) Plant-derived smoke stimulates germination of four

22. Nelson D.C., Riseborough J-A., Flematti G.R., Stevens J., Ghisalberti E.L., Dixon K.W., Smith S.M. (2009) Karrikins discovered in smoke trigger Arabidopsis seed germination by a mechanism requiring gibberellic acid synthesis and light. Plant Physiol, 149, 863873 .

23. Penman T.D., Binns D., Allen R., Shiels R., Plummer S. (2008) Germination responses of a dry sclerophyll forest soil-stored seedbank to fire related cues. Cunninghamia, 10, 547555.

24. Pérez-Fernández M.A., Rodríguez-Echeverría S. (2003) Effect of smoke, charred wood, and nitrogenous compounds on seed germination of ten species from woodland in centralwestern Spain. J Chem Ecol, 29, 237-251.

25. Read T.R., Bellairs S.M., Mulligan D.R., Lamb D. (2000) Smoke and heat effects on soil seed bank germination for the re-establishment of a native forest community in New South Wales. Austral Ecol, 25, 48-57.

26. Reyes O., Casal M. (2006a) Can smoke affect the germination of Pinus sylvestris, P. nigra, P. uncinata and P. pinaster? For Ecol Manag, 234S, S184. 
27. Reyes O., Casal M. (2006b) Seed germination of Quercus robur, Q. pyrenaica and Q. ilex and the effects of smoke, heat, ash and charcoal. Ann For Sci, 63, 205-212.

28. Reyes O., Trabaud L. (2009) Germination behaviour of 14 Mediterranean species in relation to fire factors: smoke and heat. Plant Ecol, 202, 113-121.

29. Rivas M., Reyes O., Casal M. (2006) Do high temperatures and smoke modify the germination response of Gramineae species? For Ecol Manag, 234S, S192.

30. Stevens J.C., Merritt D.J., Flematti G.R., Ghisalberti E.L., Dixon K.W. (2007) Seed germination of agricultural weeds is promoted by the butenolide 3 -methyl-2H-furo[2,3c]pyran-2-one under laboratory and field conditions. Plant Soil, 298, 113-124.

31. Tormo J., Moreira B., Pausas J.G. (2014) Field evidence of smoke-stimulated seedling emergence and establishment in Mediterranean Basin flora. J Veg Sci, 25, 771-777.

32. Tsuyuzaki S., Miyoshi C. (2009) Effects of smoke, heat, darkness and cold stratification on seed germination of 40 species in a cool temperate zone in northern Japan. Plant Biol, 11, 369-378.

33. Wada S., Reed B.M. (2011) Standardizing germination protocols for diverse raspberry and blackberry species. Sci Hortic, 132, 42-49. 